\title{
Salinity Tolerance of Select Wildflower Species in a Hydroponic Setting
}

\author{
Iryna Andrenko \\ Department of Plant and Soil Science, Texas Tech University, Lubbock, TX \\ 79409-2122
}

Thayne Montague

Department of Plant and Soil Science, Texas Tech University, Lubbock, TX 79409-2122; and Texas A\&M University, Texas A\&M AgriLife Research \& Extension Center, Lubbock, TX 79403

\section{Cynthia McKenney and Russell Plowman \\ Department of Plant and Soil Science, Texas Tech University, Lubbock, TX 79409-2122}

Additional index words. Gaura villosa, Ipomopsis rubra, landscape irrigation, sustainable landscaping, water reuse, Xanthisma texanum

\begin{abstract}
Water quality and quantity are critical issues in the Southwest United States and many other locations in the world. Use of reclaimed water for landscape irrigation can conserve potable water significantly and possibly reduce fertilizer application. A potential concern of using alternative water sources is elevated salt levels, which can have adverse effects on plant growth and aesthetic appearance. Most Texas native wildflowers are known to be hardy and easy to maintain, and are drought tolerant after establishment. In addition, native wildflowers provide wildlife habitat and support native pollinators. However, little information is available on salinity tolerance of many Texas native wildflower species. In this study, two separate hydroponic experiments were conducted to determine salt tolerance of three Texas native wildflower species: Gaura villosa Torr. (wooly gaura), Xanthisma texanum DC. (Texas sleepy daisy), and Ipomopsis rubra (L.) Wherry (standing cypress). Species were suspended in a hydroponic setting using a randomized complete block design with a control [municipal reverse-osmosis (RO) water with a nutrition solution at an electrical conductivity (EC) of $3.0 \mathrm{dS} \cdot \mathrm{m}^{-1}$ ] and three salinity treatments: 5.0, 7.0, and $11.0 \mathrm{dS} \cdot \mathrm{m}^{-1} \mathrm{EC}$. Sixty days after salinity treatments were initiated, percent survival, visual rating, fresh weight, and length measurements were recorded on root and shoot tissue. To determine tissue percentage sodium $\left(\mathrm{Na}^{+}\right)$, calcium $\left(\mathrm{Ca}^{2+}\right)$, and chloride $\left(\mathrm{Cl}^{-}\right)$, shoot and root tissues were dried and ground for tissue analysis. At the end of each experiment, total percent survival for $X$. texanum, G. villosa, and $I$. rubra were $100 \%, 94 \%$, and $76 \%$, respectively, with the greatest mortality rate at the highest salinity treatment. Shoot dry weight and plant growth index (PGI) decreased in all three species as salinity of irrigation water increased. Visual qualities of all species were mainly compromised at the highest salinity level. Ion concentrations in root and shoot tissues were affected by salinity levels and varied among species. Different mechanisms of salt tolerance (ion exclusion, salt excretion, and tissue tolerance to high concentrations of $\mathrm{Na}^{+}$or $\mathrm{Cl}^{-}$) have been observed among wildflower species, and results indicate different salt tolerance mechanisms were exhibited by each trial species. In addition, results indicate $I$. rubra can be identified as moderately salt tolerant (EC up to $7.0 \mathrm{dS} \cdot \mathrm{m}^{-1}$ ), whereas, $X$. texanum and $G$. villosa can be classified as salt tolerant ( $\mathrm{EC}$ up to $11.0 \mathrm{dS} \cdot \mathrm{m}^{-1}$ ). Results from this study suggest great potential of these native Texas wildflowers in landscapes using limited-quality irrigation water or landscapes with soil salinity concerns.
\end{abstract}

Water availability and water quality have become critical local and global issues of concern, particularly in arid and semiarid regions such as the Southwest United States (Kjelgren et al., 2000; McKenney et al., 2016; Niu and Rodriguez, 2006a). Numerous factors such as natural deficiencies in rainfall, rapid population growth, expanding urbanization, and increased freshwater demand by agricultural, industrial, and municipal sectors have contributed to water quality and quantity problems (Ganjegunte et al., 2017; Niu and Cabrera, 2010). Considering water is the 2006a; Qian et al., 2005). Moreover, reclaimed water availability increases with urban population growth (Qian et al., 2005). Use of reclaimed water can save a tremendous volume of potable water, and help with wastewater disposal (Niu and Rodriguez, 2006a). In addition, use of reclaimed water can be cost-efficient, is available year-round, may supply essential plant nutrients, and is considered to be sustainable (Hamilton et al., 2007; Qian et al., 2005). However, a concern of using reclaimed water is elevated salinity levels, which may affect plant performance (Niu et al., 2012b; Paudel et al., 2019).

Salinity, in conjunction with drought, represents one of the major threats to crop production around the world (Liu et al., 2020; Paudel et al., 2019; Veatch-Blohm et al., 2014). Salinity issues are especially critical in arid and semiarid regions, where evapotranspiration is high and precipitation is low (Yadav et al., 2011). Irrigating with lowquality water, inappropriate irrigation management strategies, high fertilization rates, and poor drainage may also exacerbate soil salinity issues (Niu et al., 2012a, 2012b). Salinity-related problems can be managed through various strategies, including leaching salts below the plant root zone, improving soil drainage, applying chemical amendments to soil, reducing soil evaporation, conducting proper irrigation management, planting salttolerant species, using phytoremediation, or a combination of these methods (Jesus et al., 2015; Kalantari et al., 2018).

Salt-tolerant plant species are characterized by the ability to resist the effects of elevated salinity levels without serious salt injury symptoms, such as reduction in growth, yield, or visual quality (Grieve et al., 2008; Liu et al., 2020). Degradation of visual quality is particularly problematic for ornamental plants (Veatch-Blohm et al., 2014). As internal salt concentrations increase, salt-induced stress may lead to plant death (Munns and Tester, 2008; Niu and Cabrera, 2010). Detrimental effects caused by salinity stress on plants include osmotic stress, ion toxicity, and ion imbalance (Munns, 2005). These effects are observed at the cellular, organ, and wholeplant level (Munns and Tester, 2008). To cope with effects of salinity stress, plants have evolved different salt tolerance mechanisms. Primary mechanisms for salinity resistance include osmotic adjustment, ion exclusion from root uptake, tissue tolerance by compartmentalization of ions into vacuoles, salt excretion by salt glands, and increased succulence to dilute salts within plant cells (Deeter, 2002; Munns, 2005; Yensen and Biel, 2006). In fact, a combination of salinity tolerance mechanisms has been used by many plant species (Deeter, 2002). In addition, a wide range of salt tolerance among landscape plant species, and even cultivars within the same species, has been reported (Niu et al., 2007; Veatch-Blohm et al., 2014). However, environmental conditions, dominant salt type, type of substrate or soil, irrigation management, and plant growth stage may affect plant 
responses to salinity stress (Niu and Cabrera, 2010; Zollinger et al., 2007).

With increased demand, and greater costs for high-quality water, implementation of water-wise landscapes is critical (Kjelgren et al., 2000; Paudel et al., 2019). Native wildflowers are considered to be excellent species in sustainable landscapes (Niu et al., 2012a). Indigenous wildflower species are well adapted to local climates, soils, insects, and diseases (Gioannini et al., 2018; LeeMäder et al., 2013). Once established, most wildflower species are known to be drought tolerant and typically do not require supplemental irrigation (Lee-Mäder et al., 2013; Niu et al., 2012a). An additional benefit of planting native wildflowers is cost efficiency associated with labor, maintenance, and use of resources. The specific benefits are a decrease in mowing frequency, noxious weed suppression, reduced water runoff, control of soil erosion, and minimization of fertilizer and pesticide application (Hopwood, 2013; Lee-Mäder et al., 2013). Planting indigenous wildflower species also ensures valuable wildlife habitat, and often serves as a reliable source of nectar and pollen for native pollinators (Gioannini et al., 2018; Hopwood, 2013). Although native wildflowers are often ignored in landscape gardening, interest in native plant species has recently risen as a result of the use of wildflowers in site restoration, improvement of local environments, and enhanced aesthetics (Cassaniti et al., 2012). For these reasons, use of native plants in arid and semiarid ecosystems with elevated soil salinity levels has gained attention (Kotzen, 2004).

For sustainable landscapes, there is a pressing need to identify salt-tolerant native wildflower species with desirable ornamental qualities (Kjelgren et al., 2009). In recent years, numerous researchers have conducted studies to assess salinity tolerance of landscape plants (Acosta-Motos et al., 2015; Cassaniti et al., 2012; Niu et al., 2010; Paudel et al., 2019; Veatch-Blohm et al., 2014; Wang et al., 2019; Wu et al., 2016). However, information on salinity tolerance of native wildflower species remains scarce (Niu et al., 2012a). Therefore, the objectives of this

Received for publication 6 Apr. 2020. Accepted for publication 8 May 2020.

Published online 10 June 2020.

We thank the Turner Seed Company, and the Department of Plant and Soil Science for funding this research.

This paper represents a portion of the thesis submitted by I. Andrenko for the MS degree in the Department of Plant and Soil Science at Texas Tech University.

Mention of a trademark, proprietary product, or vendor does not constitute a guarantee or warranty of the product by Texas Tech University and does not imply the product's approval to the exclusion of other products or vendors that also may be suitable. I.A. is the corresponding author. E-mail: andrenkoiryna@gmail.com.

This is an open access article distributed under the CC BY-NC-ND license (https://creativecommons. org/licenses/by-nc-nd/4.0/).
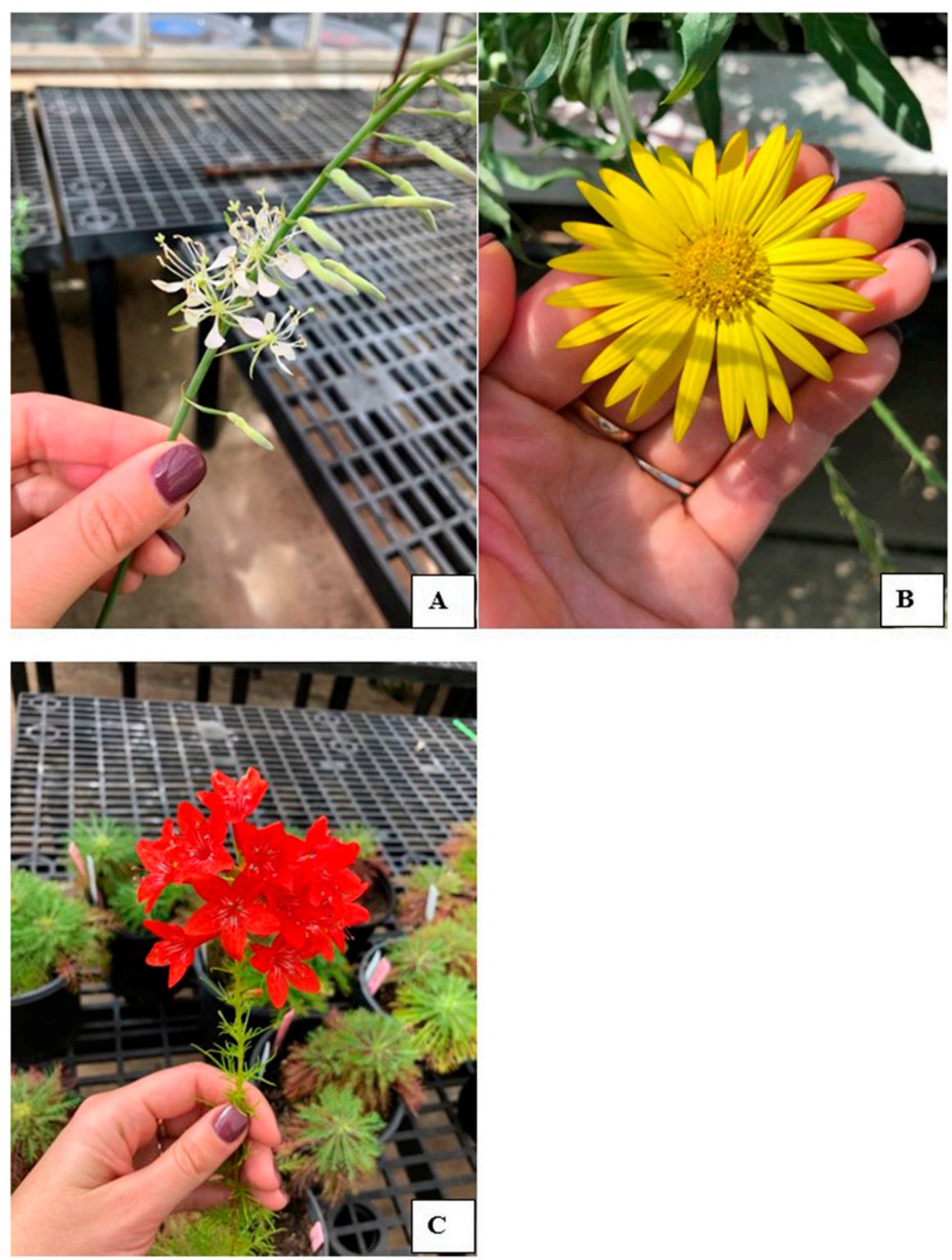

Fig. 1. Flowers of (A) Gaura villosa, (B) Xanthisma texanum, and (C) Ipomopsis rubra.

study are to identify the growth response and salt tolerance mechanisms of three wildflower species exposed to a range of salinity treatments. Results will provide baseline information on the relative salt tolerance of tested species, and will enhance planting recommendations for salt-tolerant wildflower species in areas with poor water quality or soil salinity concerns. Selected wildflower species for this study were Gaura villosa (gaura), Xanthisma texanum (sleepy daisy), and Ipomopsis rubra (standing cypress) (Fig. 1). Each species is native to North America, requires partial shade to full sun, thrives in sandy to gravely poor soils, and is thought to exhibit potential as an ornamental landscape species (Diggs et al., 1999; U.S. Department of Agriculture, 2018; Wasowski and Wasowski, 2000).

\section{Materials and Methods}

Plant materials, preparation of salinity experiment, and growing conditions. Hydro- ponic experiments were conducted during Spring 2017 (Expt. 1) and Spring 2019 (Expt. 2 ). Experiments were conducted at the Texas Tech University Greenhouse complex (lat. $33^{\circ} 35^{\prime} 03.0^{\prime \prime} \mathrm{N}$, long. $101^{\circ} 53^{\prime} 13.0^{\prime \prime} \mathrm{W}$; elevation, $990 \mathrm{~m})$. Seeds of $G$. villosa, $X$. texanum, and I. rubra were acquired from the Texas Tech University Raider Wildflower Collection ${ }^{\mathrm{TM}}$. Seeds of wildflowers were sown Oct. 2016 (Expt. 1), and Sept. 2018 (Expt. 2). Seeds were sown $5 \mathrm{~mm}$ deep in aluminum pans $(15.6 \times 9.5 \times 5.1 \mathrm{~cm})$ filled with professional growing mix (Sun Gro Horticulture, Agawam, MA). After sowing, seeds were watered and topped with a thin layer of vermiculite for water retention. For disease control, germination pans were drenched with a fungicide (Captan WP; Bonide Products Inc., Oriskany, NY) and covered with a clear plastic wrap to preserve moisture and prevent pathogen intrusion. Wrapped pans were placed in a refrigerator and stratified at 4 to $6{ }^{\circ} \mathrm{C}$ for 9 weeks. 


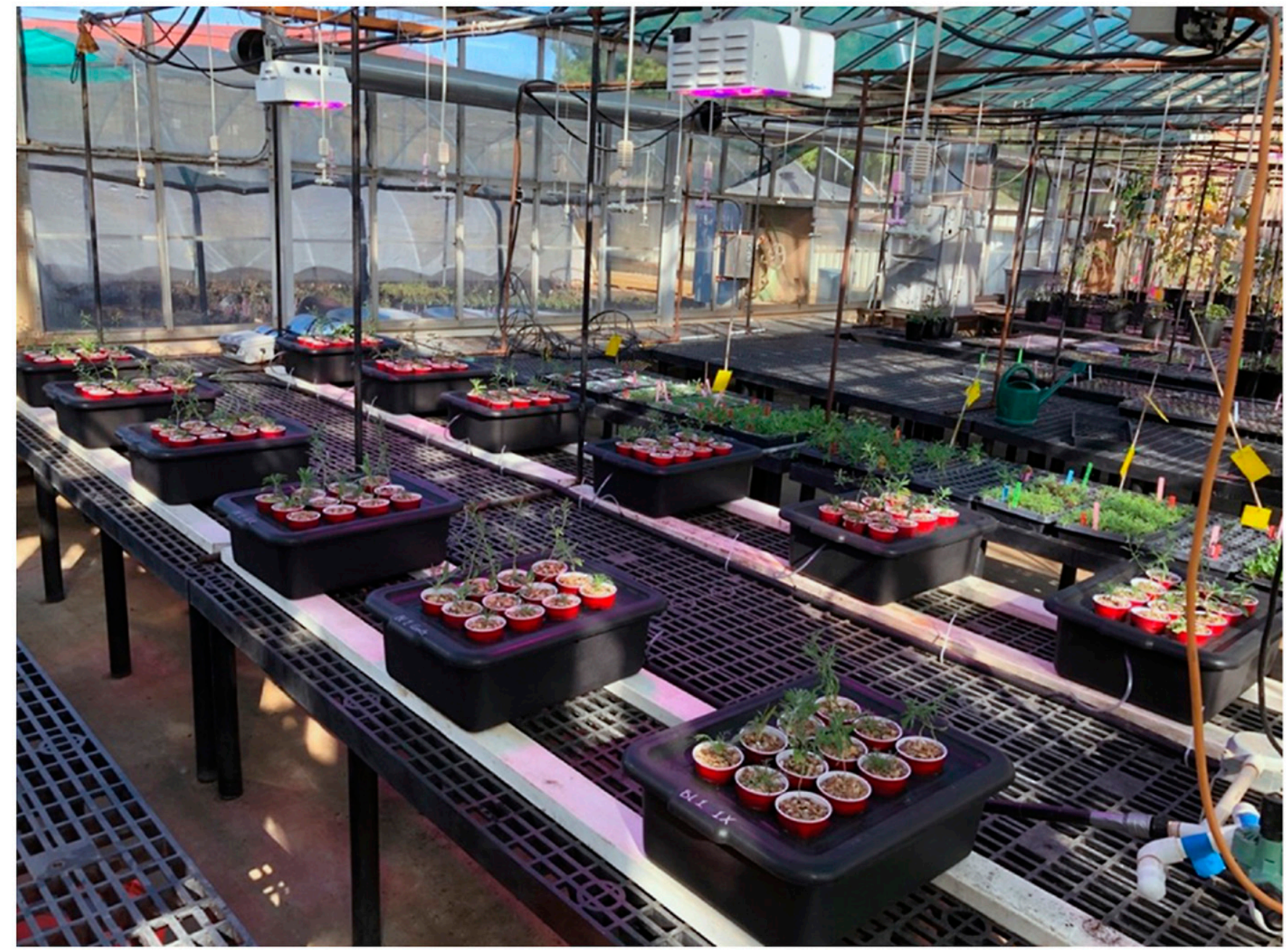

Fig. 2. Hydroponic setting with experimental plants at the beginning of Expt. 2 (2019).

Subsequently, experimental pans were removed from the cooler, unwrapped, and placed on a greenhouse bench with heating mats. To help minimize air temperature throughout the experiments, green shadecloth with 60\% light transmission (Agfabric, Corona, CA) was placed over the exterior roof of the greenhouse. Therefore, during each experiment, greenhouse air temperature was maintained at $24.4{ }^{\circ} \mathrm{C} \pm 3.3^{\circ} \mathrm{C}$ during the day and $21.1^{\circ} \mathrm{C} \pm 2.8^{\circ} \mathrm{C}$ at night. Three times each day, an overhead mist system irrigated seedlings for 2 to $3 \mathrm{~min}$. When emerged seedlings reached the true-leaf stage, seedlings were transplanted into 58-cell plug trays (58 Nova Plug Tray; ITML Horticultural Products Inc., Lewiston, NY). The volume of each cell equaled $43 \mathrm{~mL}$ and was filled with previously described media. During the plug tray growing stage, seedlings were fertigated with a $20 \mathrm{~N}-8.7 \mathrm{P}-16.6 \mathrm{~K}$ fertilizer (Peters Professional 20-20-20 General Purpose; ICL Specialty Fertilizers, Dublin, $\mathrm{OH}$ ) at a rate of $0.1 \mathrm{~g} \cdot \mathrm{L}^{-1}$ once every 2 weeks. During seed germination, and throughout each experiment, supplemental lighting was provided on a constant basis by two lightemitting diode (LED) grow lights (Pro 325; LumiGrow Inc., Emeryville, CA) set to equal proportions of red, white, and blue light. On

Table 1. Electrical conductivity $(\mathrm{EC})$, sodium chloride $(\mathrm{NaCl})$, and calcium chloride $\left(\mathrm{CaCl}_{2}\right)$ concentrations of the control and saline hydroponic solutions for both experiments.

\begin{tabular}{|c|c|c|c|c|c|}
\hline Treatment & $\mathrm{EC}\left(\mathrm{dS} \cdot \mathrm{m}^{-1}\right)^{\mathrm{z}}$ & $\mathrm{NaCl}(\mathrm{mm})$ & $\mathrm{CaCl}_{2}(\mathrm{~mm})$ & $\mathrm{NaCl}(\mathrm{g})^{\mathrm{y}}$ & $\mathrm{CaCl}_{2}(\mathrm{~g})$ \\
\hline Control & 3.0 & - & - & - & - \\
\hline $1 / 2 \times$ & 5.0 & 10 & 5 & 11.7 & 11.1 \\
\hline $1 \times$ & 7.0 & 20 & 10 & 23.4 & 22.2 \\
\hline $2 x$ & 11.0 & 40 & 20 & 46.8 & 44.4 \\
\hline
\end{tabular}

${ }^{\mathrm{z}} \mathrm{EC}$ of treatment hydroponic solutions, including salts, nutrient solution, and reverse osmosis (RO) water ${ }^{y}$ Calculated amount of salt $\left(\mathrm{NaCl}\right.$ or $\left.\mathrm{CaCl}_{2}\right)$ for each tub $(20 \mathrm{~L} \mathrm{RO}$ water $)$.

Table 2. Mean survival percentage of three hydroponically grown wildflower species in salinity solutions with an electrical conductivity (EC) of 3.0 (control, reverse-osmosis water and nutrient solution), 5.0, 7.0 , and $11.0 \mathrm{dS} \cdot \mathrm{m}^{-1}$

\begin{tabular}{lcccc}
\hline & \multicolumn{4}{c}{ Survival (\%) } \\
\cline { 2 - 5 } Species & $\mathrm{EC}=3.0$ & $\mathrm{EC}=5.0$ & $\mathrm{EC}=7.0$ & $\mathrm{EC}=11.0$ \\
\hline Gaura villosa & 100 & 87.5 & 100 & 87.5 \\
Xanthisma texanum & 100 & 100 & 100 & 100 \\
Ipomopsis rubra & $87.5 \mathrm{a}^{\mathrm{z}}$ & $87.5 \mathrm{a}$ & $83.3 \mathrm{a}$ & $45.8 \mathrm{~b}$ \\
\hline
\end{tabular}

${ }_{\mathrm{z}}$ Means without letters or with the same lowercase letters in the same row are not different (among different treatments within the same species). Mean separation conducted by Student-Newman-Keuls multiple comparison at $P \leq 0.05$. Plants grown in salinity treatments for $60 \mathrm{~d}$. Data from 2017 and 2019 experiments were combined.

numerous occasions, midday photosynthetic active radiation was quantified with a LICOR LI-190SA quantum sensor (LI-COR Biosciences, Lincoln, NE). Photosynthetic photon flux density $(P P F D)$ was estimated over the 400 - to $700-\mathrm{nm}$ range. During the experiments, the mean midday $P P F D$ equaled $564 \mu \mathrm{mol} \cdot \mathrm{m}^{-2} \cdot \mathrm{s}^{-1}$. After 10 weeks in plug trays, uniform seedlings were selected to transfer into the hydroponics system on 18 19 Feb. 2017 (Expt. 1) and 19-20 Jan. 2019 (Expt. 2). 
Hydroponic system. A hydroponic system similar to systems constructed by McKenney et al. (2016) and Pessarakli and Kopec (2009) were used for this experiment. Twelve plastic tubs $(53 \times 38 \times 18 \mathrm{~cm})$ were modified to hold 12 plants in each tub. Throughout each experiment, tub water volume was maintained at $20 \mathrm{~L}$, and tubs were placed on a greenhouse bench (Fig. 2). Plastic cups (diameter, 7.5 $\mathrm{cm} ; 250 \mathrm{~mL}$ ) (SOLO cups; Dart Container Corporation, Mason, MI) were modified and used as plant containers (Fig. 2). Before transplanting into the hydroponic system, roots of experimental seedlings were washed thoroughly. A single seedling plant was placed in each cup and, before filling with pea gravel (diameter, $7 \pm 3 \mathrm{~mm}$ ), the bottom of each cup was removed and covered with a fine mesh screen. Within each tub lid, cups were arranged in four rows with three cups in each row (Fig. 2). The distance between cups was $2.5 \mathrm{~cm}$. In addition, throughout each experiment, air was supplied to plant roots by an aeration system (McKenney et al., 2016; Pessarakli and Kopec, 2009).

Saline solution treatments. Nutrients were provided to plants by dissolving one $907-\mathrm{g}$ bag of $6 \mathrm{~N}-5.2 \mathrm{P}-23.2 \mathrm{~K}$ in $3.8 \mathrm{~L}$ water, and one $907-\mathrm{g}$ bag of $15 \mathrm{~N}-0 \mathrm{P}-0 \mathrm{~K}$ Verti-Gro Hydroponic Plant Nutrients (Verti-Gro, Summerfield, FL) in another $3.8 \mathrm{~L}$ water. Then, $14.8 \mathrm{~mL}$ of each of these concentrated plant nutrient solutions was applied to every $3.8 \mathrm{~L}$ of water in each experimental tub. Before initiation of salinity treatments, plants were allowed to acclimatize to city-supplied RO water with nutrient solution for 1 week. After 1 week of acclimatization, salinity levels were increased gradually every week to minimize the possibility of salinity shock. Salinity treatments with an EC of 3.0 (citysupplied RO water with nutrient solution = control), 5.0, 7.0, and $11.0 \mathrm{dS} \cdot \mathrm{m}^{-1}$ were prepared by adding calculated amounts of sodium chloride $(\mathrm{NaCl})$ and calcium chloride $\left(\mathrm{CaCl}_{2}\right)$ to $\mathrm{RO}$ water with nutrient solution. The weight ratio of $\mathrm{NaCl}: \mathrm{CaCl}_{2}$ was $2: 1$ to mimic the local source of reclaimed water (McKenney et al., 2016; Paudel et al., 2019) (Table 1). These EC levels were chosen based on the plant salinity tolerance scale, where plants could be divided into five categories: sensitive $\left(<3 \mathrm{dS} \cdot \mathrm{m}^{-1}\right)$, moderately sensitive (3-6 dS $\left.\cdot \mathrm{m}^{-1}\right)$, moderately tolerant $\left(6-8 \mathrm{dS} \cdot \mathrm{m}^{-1}\right)$, tolerant $\left(8-10 \mathrm{dS} \cdot \mathrm{m}^{-1}\right)$, and highly tolerant $\left(>10 \mathrm{dS} \cdot \mathrm{m}^{-1}\right)$ (Miyamoto et al., 2004).

Maintenance. To avoid nutrient deficiency or nutrient imbalance, and to prevent microbial contamination, tubs were emptied, scrubbed, and remixed every 2 weeks. Tubs were replenished with $\mathrm{RO}$ water and nutrient solution as needed to maintain accurate EC levels (McKenney et al., 2016; Niu et al., 2018). To ensure constant salinity levels, the EC of each hydroponic solution was measured with a Combo $\mathrm{pH} /$ Conductivity/TDS Tester (Hanna Instruments, Smithfield, RI) several times each week. Two insecticides [Tame/Orthene (A Prescription Treatment; Whitmire Micro-Gen Research Laboratories Inc., St. Louis, MO) and Pyrethrum (BASF
Corporation, Research Triangle Park, NC)] were applied at recommended rates several times during both experiments to control aphids (Aphidoidea), spider mites (Tetranychidae), thrips (Thripidae), and whiteflies (Aleyrodidae).
Measurements. Salinity treatments were ended $60 \mathrm{~d}$ after the initial treatments. At this time, plants were evaluated for visual rating, and growth data such as survival percentage, fresh shoot weight, fresh root weight, and

Table 3. Visual rating (0-9) of three hydroponically grown wildflower species at three levels of salinity treatment in a hydroponic solution with an electrical conductivity (EC) of 3.0 (control, reverse-osmosis water and nutrient solution), 5.0, 7.0, and $11.0 \mathrm{dS} \cdot \mathrm{m}^{-1}$.

\begin{tabular}{lcccc}
\hline & \multicolumn{4}{c}{ Visual rating } \\
\cline { 2 - 5 } Species & $\mathrm{EC}=3.0$ & $\mathrm{EC}=5.0$ & $\mathrm{EC}=7.0$ & $\mathrm{EC}=11.0$ \\
\hline Gaura villosa & 6.8 & 6.5 & 6.6 & 5.5 \\
Xanthisma texanum & 7.6 & 7.3 & 7.5 & 6.6 \\
Ipomopsis rubra & $6.6 \mathrm{a}^{\mathrm{y}}$ & $6.2 \mathrm{a}$ & $5.9 \mathrm{a}$ & $2.7 \mathrm{~b}$ \\
\hline
\end{tabular}

${ }^{\mathrm{z}}$ Rating of $0=$ dead; 9 = outstanding plant appearance.

${ }^{\mathrm{y}}$ Means without letters or with the same lowercase letters in the same row are not different (among different treatments within the same species). Mean separation conducted by Student-Newman-Keuls multiple comparison at $P \leq 0.05$. Plants grown in salinity treatments for $60 \mathrm{~d}$. Data from 2017 and 2019 experiments were combined.

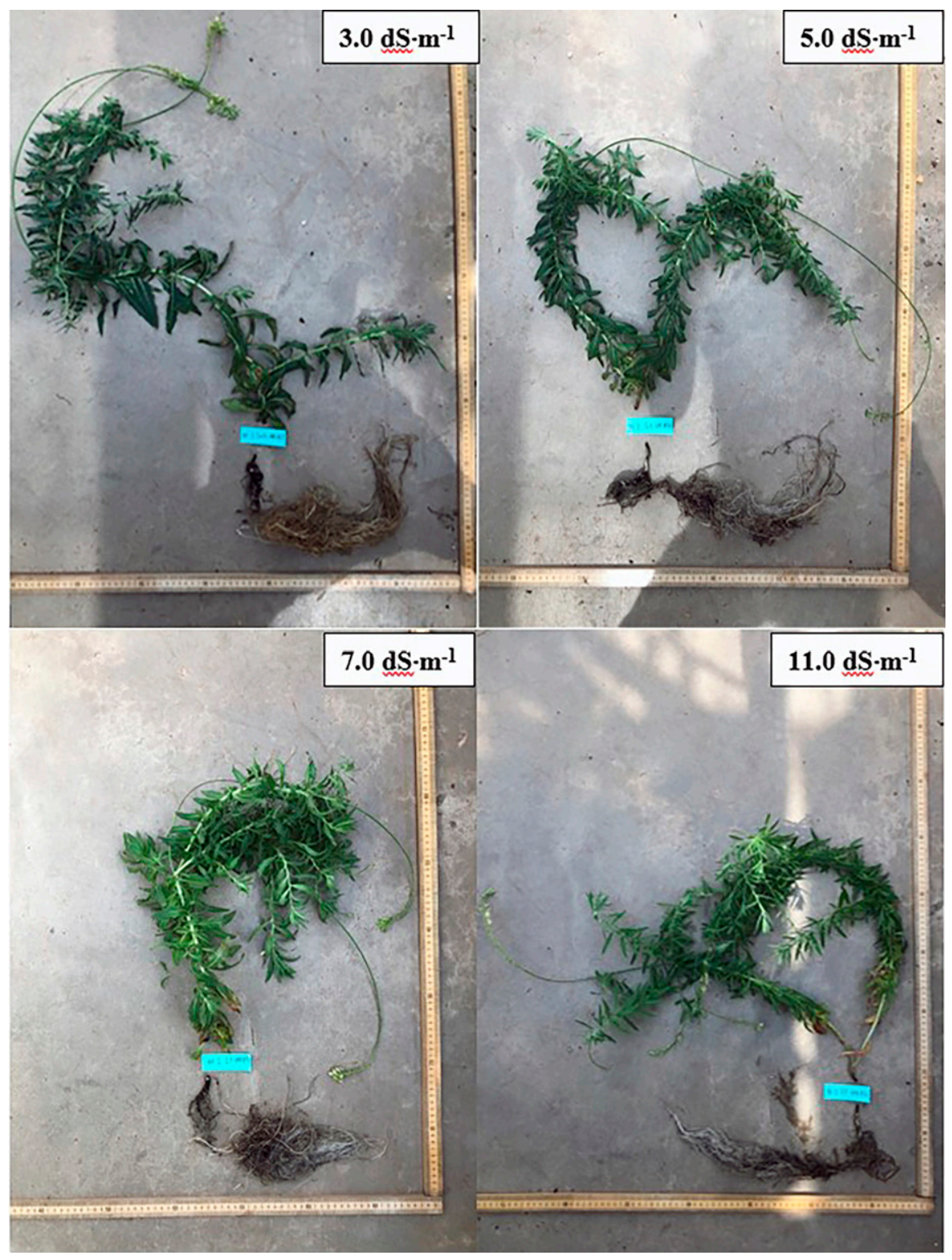

Fig. 3. Representative photos of hydroponically grown Gaura villosa at control [reverse-osmosis water and nutrient solution, with an electrical conductivity (EC) of $3.0 \mathrm{dS} \cdot \mathrm{m}^{-1}$ ] and three levels of saline solution with an EC of 5.0, 7.0, and $11.0 \mathrm{dS} \cdot \mathrm{m}^{-1}$. Photos taken at the termination of Expt. 2 (2019). 
PGI were recorded. Survival percentage was calculated as

$$
S=\frac{A}{B} \times 100,
$$

where $S$ is percent survivability, $A$ is the number of surviving plants of each species within the treatment at the end of the experiment, and $B$ is the total number of plants of the same species within the same salinity treatment. Visual ratings, which represent the aesthetic value of ornamental plants and is an important component in salt-tolerant plant identification (Cassaniti et al., 2012), were taken using a modified scale from the $\mathrm{Na}$ tional Turfgrass Evaluation Program (Morris and Shearman, 2000). The modified scale ranged from 0 to 9 points, where 0 corresponds to a dead plant and 9 represents outstanding plant appearance relative to presumed commercial value. In general, a rating of 6 or greater is considered acceptable for landscape purposes (McKenney et al., 2016). Percentage of foliar damage, flowering, and growth characteristics were key components in assigning a plant's visual rating (McKenney et al., 2016; Niu and Cabrera, 2010; Niu et al., 2012a). The PGI was calculated using the following equation:

$$
\text { PGI }=\frac{W 1+W 2+H}{3},
$$

where $W 1$ represents the plant canopy width measured in the east-west direction, W2 represents the plant width measured in north-south direction, and $H$ is the plant height (Ferrarezi and Bailey, 2019). Plants grown in the same tub often had roots twisted and bound together. However, roots of each plant were divided carefully, with minimal to no effect on estimated dry root weight. Shoot and root tissues were separated, and collected tissues were dried for $10 \mathrm{~d}$ at $45^{\circ} \mathrm{C}$. The ratio of root dry weight to shoot dry weight is a commonly used parameter when assessing plant response to salinity (Acosta-Motos et al., 2015). Dry root to dry shoot weight ratios were calculated from recorded shoot and root dry weights for each plant. Dried tissues were powdered with a Cyclone Sample Mill (Direct Drive 3010-014; UDY Corporation, Fort Collins, CO). Powdered samples were sent to a commercial laboratory and analyzed to determine salt ion content (i.e., percentage $\mathrm{Na}^{+}, \mathrm{Ca}^{2+}$, and $\mathrm{Cl}^{-}$).

Experimental design and statistical analysis. Each experiment followed a randomized complete block design with three blocks. Each block consisted of four tubs, and within each tub one of the four salinity treatments was assigned randomly. Therefore, across the three blocks there were four samples of each species within each tub, resulting in a total of 12 samples of each species within each salinity treatment (Fig. 2). Because of different growth habits of tested plant species, a one-way analysis of variance was conducted separately for each wildflower species for all data ( $\mathrm{Wu}$ et al., 2016). To determine differences among treatments, a Student-Newman-Keuls (SNK)

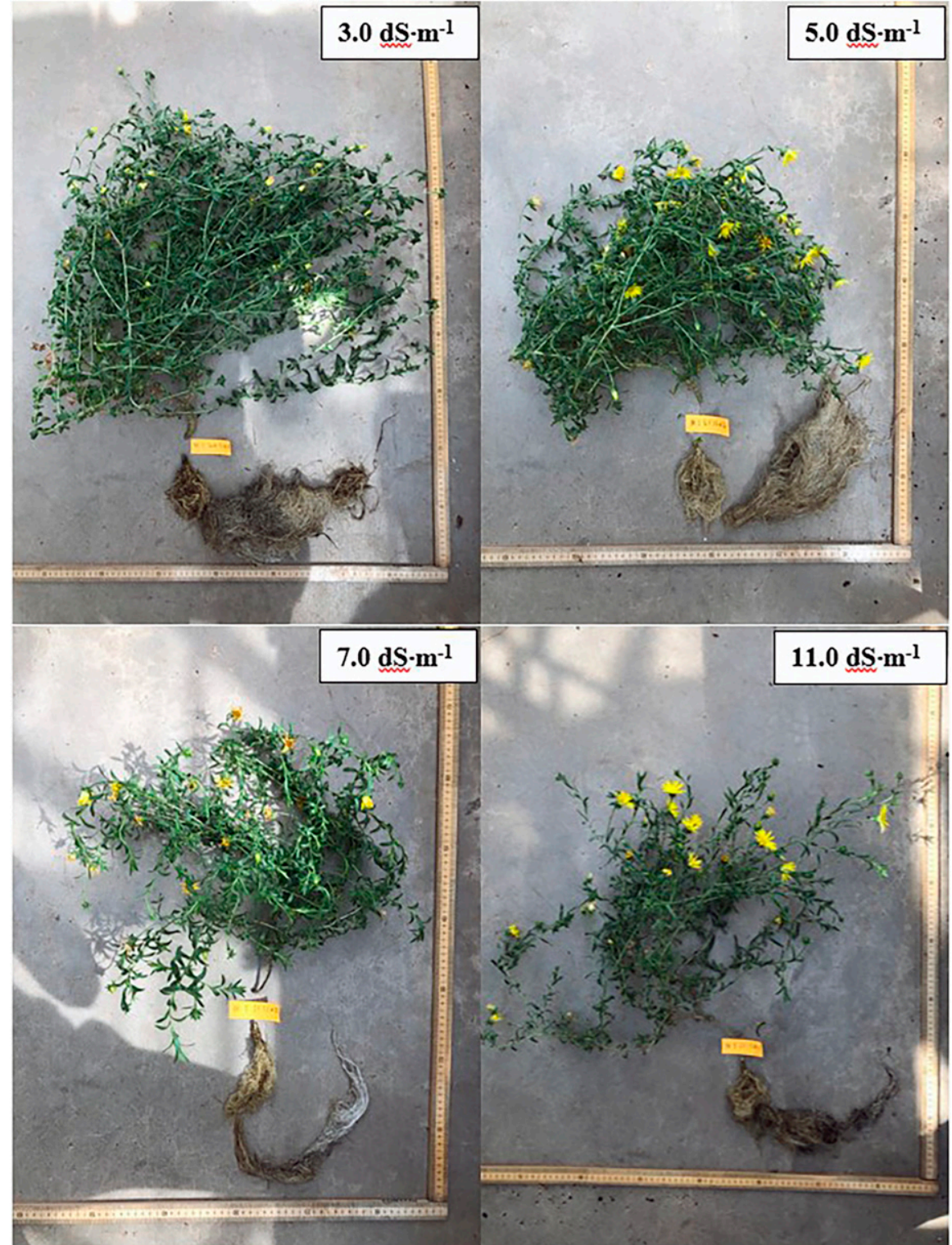

Fig. 4. Representative photos of hydroponically grown Xanthisma texanum at control [reverse-osmosis water and nutrient solution, with an electrical conductivity (EC) of $\left.3.0 \mathrm{dS} \cdot \mathrm{m}^{-1}\right]$ and three levels of saline solution with an EC of 5.0, 7.0, and $11.0 \mathrm{dS} \cdot \mathrm{m}^{-1}$. Photos taken at the termination of Expt. 2 (2019).

multiple comparison at $P \leq 0.05$ was performed (Niu et al., 2012a). When the salinity treatment effect was significant for $\mathrm{Na}^{+}, \mathrm{Ca}^{2+}$, and $\mathrm{Cl}^{-}$concentrations, regression analysis was performed (with EC as the independent variable and ion percentage as the dependent variable) using PROC REG (Niu et al., 2010, 2012a). All data were analyzed using SAS software (Version 9.1.3; SAS Institute Inc., Cary, NC). Because outcomes from each experiment exhibited similar results, data from Expt. 1 and Expt. 2 were pooled.

\section{Results and Discussion}

Survival percentage. Survivability is a key parameter for the evaluation of ornamental plant performance exposed to a variety of stress factors, including salt stress (Niu et al., 2012b). In addition, survival percentage of landscape plants should be a vital factor for planting considerations (Cassaniti et al., 2012). Survival percentages across all treatments for G. villosa, X. texanum, and I. rubra equaled $94 \%, 100 \%$, and $76 \%$, respectively, with the greatest mortality at the highest salinity treatment (Table 2). Survival percentage differences were not found among salinity treatments for $G$. villosa and $X$. texanum. However, G. villosa plants had decreased survivability $(87.5 \%)$ at the 5.0 and $11.0-\mathrm{dS} \cdot \mathrm{m}^{-1}$ salinity treatments when compared with the control $\left(3.0 \mathrm{dS} \cdot \mathrm{m}^{-1}\right)$ and the $7.0-\mathrm{dS} \cdot \mathrm{m}^{-1}$ salinity treatments. A similar nonlinear response to increased salinity levels corresponds to a growth curve of salttolerant glycophytes (Kreeb, 1974). A bimodal pattern was also found in percent 
germination recovery of Atriplex acanthocarpa (armed saltbush) seeds treated with various concentrations of $\mathrm{NaCl}$ (Gaylord and Egan, 2006). In addition, a similar trend was found in shoot dry weight of Helenium amarum (helenium) in response to saline water irrigation (Niu et al., 2010). For I. rubra, survival percentage was less $(45.8 \%)$ at an EC of 11.0 $\mathrm{dS} \cdot \mathrm{m}^{-1}$ compared with all other EC levels (Table 2). The greater mortality rate for $G$. villosa and I. rubra plants at the highest salinity treatment level could be attributed to an adverse response to salt stress (Niu et al., 2012a). A high survival percentage, in the case of $X$. texanum plants, suggests a greater capacity of this species to cope with salt stress by adopting certain tolerance mechanisms (Niu et al., 2012a). For example, Wu et al. (2016) found $100 \%$ survivability of Stachys coccinea (Texas betony) at an EC of $10.0 \mathrm{dS} \cdot \mathrm{m}^{-1}$, with the greatest $\mathrm{Na}^{+}$accumulation in plant tissue compared with other tested Lamiaceae ornamental species. Their data indicated Texas betony had high tissue tolerance to increased $\mathrm{Na}^{+}$concentrations (Wu et al., 2016). In our experiment, reduced survivability of $I$. rubra plants across treatments could be attributed to the small, weak root system found in the I. rubra plants (Table 2). In addition, hydroponic growing conditions of the experiments (plant roots were submerged in irrigation solution) may not have been optimal for I. rubra (Wasowski and Wasowski, 2000). For example, Helictotrichon sempervirens (blue oat grass) also prefers dry, well-drained soil conditions. McKenney et al. (2016) reported that blue oat grass plants did not establish well during salinity tolerance hydroponic studies.

Visual rating. Before destructive data were taken, plants were evaluated based on visual quality (Table 3 ). The visual rating of G. villosa (Fig. 3, Table 3) and X. texanum (Fig. 4, Table 3) varied from 5.5 to 6.8, and 6.6 to 7.6 , respectively. The lowest ratings were found at the highest salinity levels. For I. rubra, visual ratings ranged from 2.7 to 6.6 (Fig. 5, Table 3), with the lowest visual quality at the highest salinity level, which likely caused the greater mortality rate (Table 2). Even though differences were not found among salinity treatments for G. villosa and $X$. texanum plants, typical salinity injury symptoms were observed for all three wildflower species, with greater salinity symptoms found as hydroponic water EC increased (Fig. 6). Salinity symptoms for $G$. villosa included premature leaf drop, leaf discoloration, and growth reduction. For $X$. texanum, typical salinity injury symptoms accounted for growth reduction, leaf chlorosis, and necrosis of older leaves. Typical symptoms of salt injury for I. rubra consisted of leaf tip burn, lower leaf necrosis, and eventual plant death as salinity levels increased. In previous research, similar symptoms were observed in response to irrigation with low-quality, high-EC water in Aquilegia barnebyi (oil shale columbine) (Paudel et al., 2019), Cornus alba (tatarian dogwood) (Liu et al., 2020) Lavandula angustifolia (English lavender), Narcissus sp. (daffodil cultivars) (Veatch-Blohm et al., 2014), Mirabilis multiflora (Colorado four o'clock) (Zollinger et al., 2007), and Penstemon eatonii (firecracker penstemon) (Niu and Rodriguez, 2006a) plants.

Plant growth index. Only the PGI of $X$. texanum differed among salinity treatments. However, all three wildflower species had a lower PGI at an EC of $11.0 \mathrm{dS} \cdot \mathrm{m}^{-1}$; and for each species, PGI increased with decreasing hydroponic solution salinity (Fig. 7A). PGI results exhibit a similar pattern when compared with trends in shoot dry weight (Fig. 7C). For example, Veatch-Blohm et al. (2014) found a similar reduction in growth rate and biomass production in Narcissus sp. (daffodil cultivars) in response to salinities $\geq 100 \mathrm{~mm} \mathrm{NaCl}$, with the greatest decline in the highest salinity levels (200 and $300 \mathrm{~mm}$ $\mathrm{NaCl}$ ). Previous research has also revealed
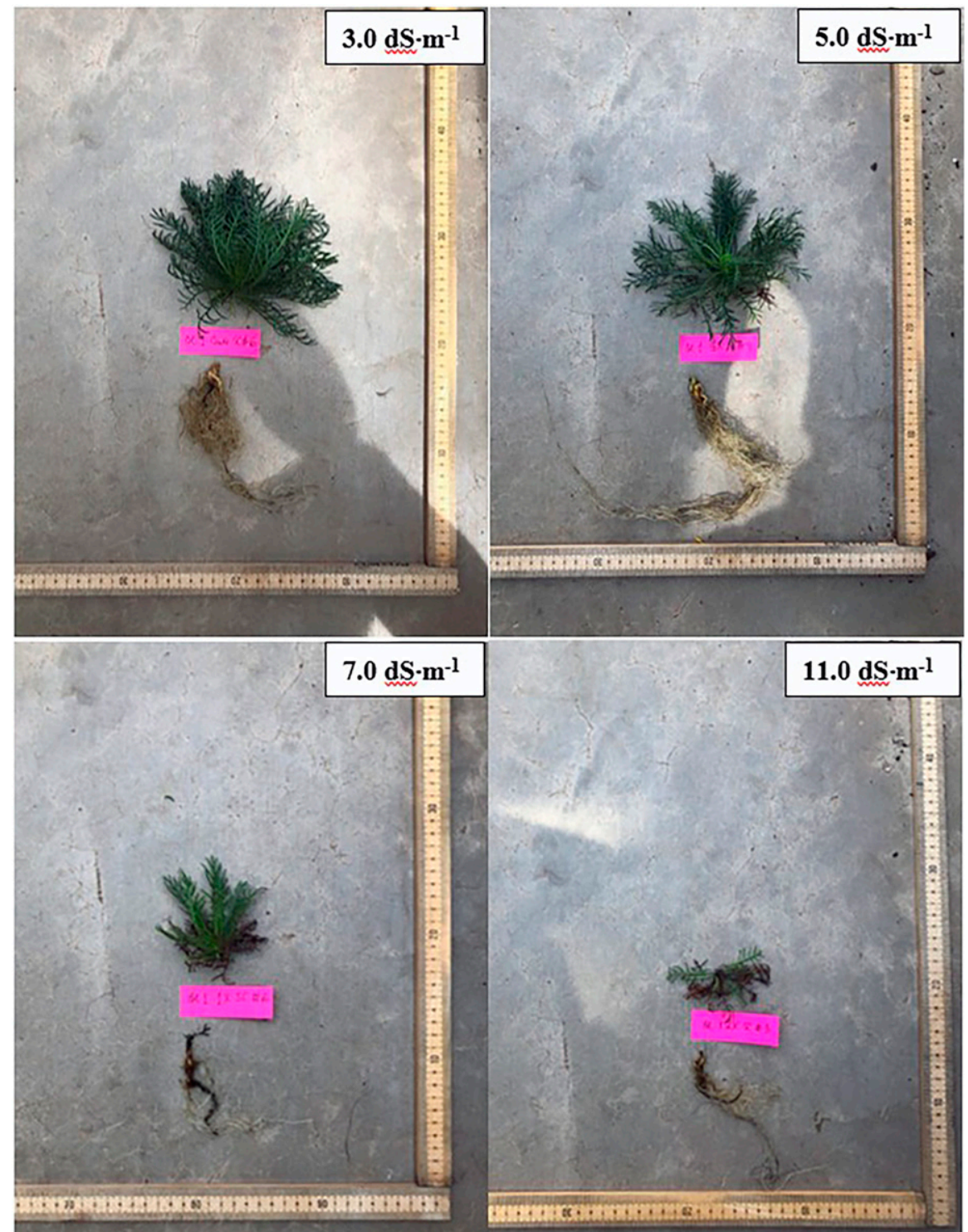

the PGI of Capsicum annuum 'Black Pearl' (ornamental pepper 'Black Pearl'), Helenium amarum (helenium), and Catharanthus roseus 'Rose' (vinca) decreased linearly with increased salinity (Niu et al., 2010).

Root dry weight. Root dry weight of all three wildflower species was unaffected by irrigation water salinity (Fig. 7B). Furthermore, no progressive decline in dry root weight was observed in response to increased salinity. Our results are in contrast to previous research that indicated a decline in root dry weight is common for landscape plants exposed to greater salinity concentrations (Acosta-Motos et al., 2015; Hooks and Niu, 2019). However, Trajkova et al. (2006) reported Cucumis sativus (cucumber) dry root weight was unaffected by increased $\mathrm{NaCl}$ salinity, and high concentrations of $\mathrm{CaCl}_{2}$ in hydroponic solution increased the root dry mass of cucumber plants.

Fig. 5. Representative photos of hydroponically grown Ipomopsis rubra at control [reverse-osmosis water and nutrient solution, with an electrical conductivity (EC) of $3.0 \mathrm{dS} \cdot \mathrm{m}^{-1}$ ] and three levels of saline solution with an EC of 5.0, 7.0, and $11.0 \mathrm{dS} \cdot \mathrm{m}^{-1}$. Photos taken at the termination of Expt. 2 (2019). 

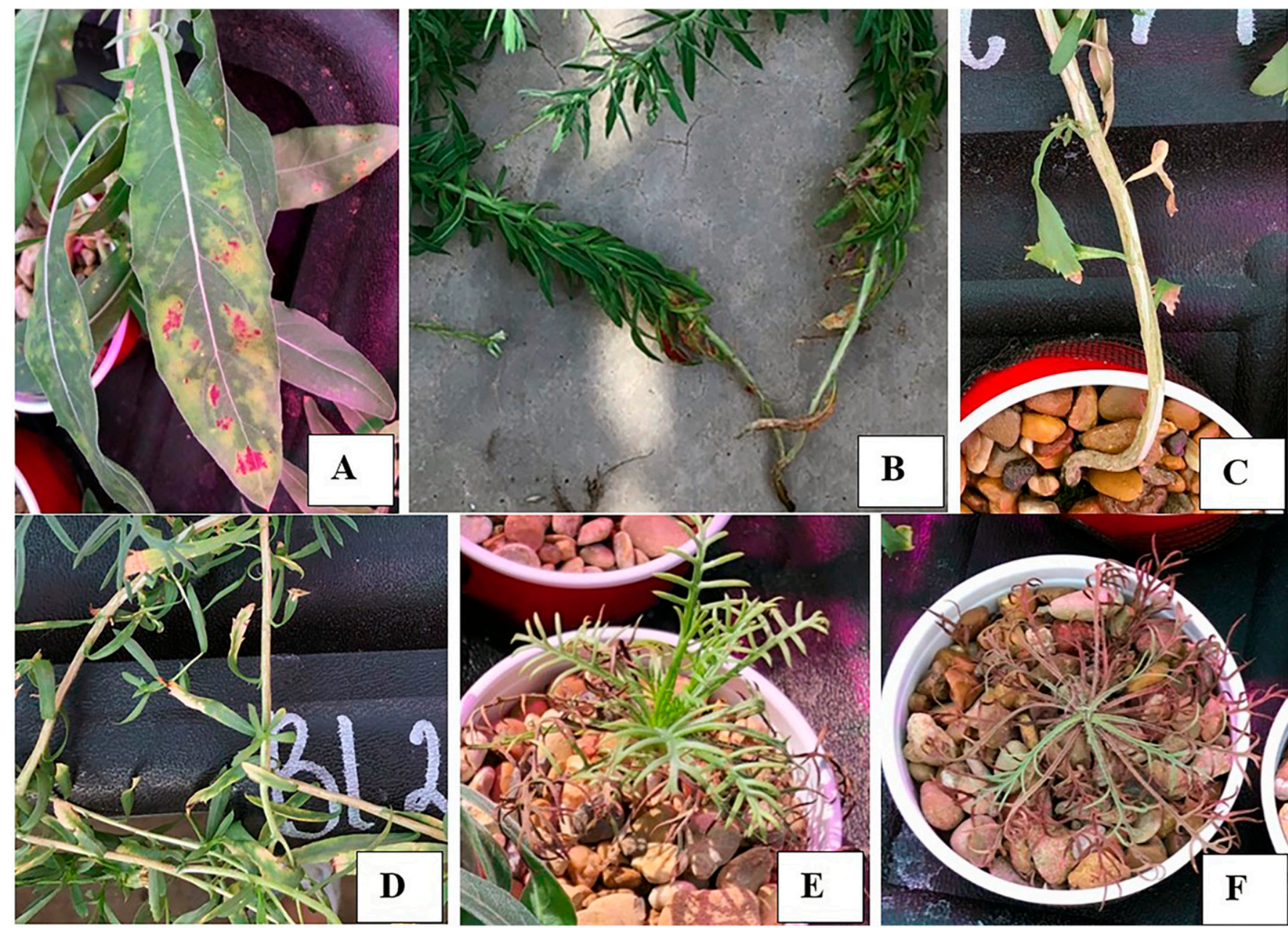

Fig. 6. Symptoms of salt injury. Leaf discoloration in (A) Gaura villosa, (B) premature leaf drop in G. villosa, (C) leaf necrosis in Xanthisma texanum, (D) leaf chlorosis in X. texanum, (E) lower leaf necrosis in Ipomopsis rubra, and (F) plant death in I. rubra. Photos taken at the termination of Expt. 2 (2019).

Shoot dry weight. Shoot dry weight of $X$. texanum was affected negatively by increasing salinity concentrations. Specifically, shoot dry weight of $X$. texanum plants decreased by $37 \%$ in the greatest salinity treatment $\left(11.0 \mathrm{dS} \cdot \mathrm{m}^{-1}\right)$ compared with the control (3.0 dS.m ${ }^{-1}$; Fig. 7C). However, shoot dry weight of $G$. villosa did not differ across salinity treatments, although a progressive decline in shoot mass of $G$. villosa was clearly seen as salinity levels increased (Fig. 7C). In addition, there were no differences in the shoot dry weight of I. rubra among salinity treatments (Fig. 7C), which could be explained by I. rubra's compact rosette growth habit (Diggs et al., 1999). A reduction in shoot dry weight is one of the typical symptoms of osmotic stress caused by elevated salinity levels (Montesano and Van Iersel, 2007; Wang et al., 2019). For example, a linear decrease in shoot dry weight of Capsicum annuum 'Black Pearl' (ornamental pepper 'Black Pearl') and Catharanthus roseus 'Rose' (vinca 'Rose') was observed as the EC of irrigation water increased from 0.8 to $7.8 \mathrm{dS} \cdot \mathrm{m}^{-1}$ (Niu et al., 2010). Liu et al. (2020) also found a $45.2 \%$ decrease in shoot dry weight of Cornus alba (tatarian dogwood) seedlings grown at an EC of 10.0
$\mathrm{dS} \cdot \mathrm{m}^{-1}$ when compared with seedlings grown at an EC of $1.2 \mathrm{dS} \cdot \mathrm{m}^{-1}$. Similar to results of shoot dry weight of I. rubra from our study, no differences in shoot dry weight of Capsicum annuum 'Purple Flash' (ornamental pepper 'Purple Flash') were found among four salinity treatments (Niu et al., 2010). Overall, species and even cultivar-specific shoot dry weight responses to salt stress are reported in numerous studies (Niu and Cabrera, 2010; Niu et al., 2010; Zollinger et al., 2007). Although, in our study, shoot dry weight tended to decrease in all species as irrigation water EC increased, compact ornamental plants could be more suitable for certain landscapes. In addition, compact plants potentially reduce the need of pruning and other maintenance requirements, and thus lessen landscape maintenance input (McKenney et al., 2016; Niu et al., 2007a; VeatchBlohm et al., 2014).

Root-to-shoot ratio. For many species, the root-to-shoot ratio generally increases with an increase in salinity concentration. This increased ratio indicates reduced shoot production compared with root production as EC concentration increases (Acosta-Motos et al., 2015). For G. villosa plants, the root-to-shoot ratio increased as salinity levels increased
(Fig. 7D). Niu and Rodriguez (2006b) also reported an increase in the root-to-shoot ratio of Teucrium chamaedrys (wall germander) as salinity increased. In general, the greater reduction in shoot growth compared with root growth is attributed primarily to osmotic stress (Montesano and Van Iersel, 2007). The root-to-shoot ratio of $X$. texanum plants was not different between salinity treatments (Fig. 7D), although, the aforementioned trend still can be observed. Similarly, the root-to-shoot ratio of Ceratostigma plumbaginoides (blue leadwood) and Gazania rigens (treasure-flower) was unaffected by saline water irrigation (Niu and Rodriguez, 2006b). For I. rubra plants, differences were not found in the root-to-shoot ratio among salinity treatments. In addition, an increase in the root-to-shoot ratio as salinity levels increased was not detected. The root-to-shoot ratio of I. rubra gradually decreased from an EC of $3.0 \mathrm{dS} \cdot \mathrm{m}^{-1}$ to an EC of $7.0 \mathrm{dS} \cdot \mathrm{m}^{-1}$, and then increased from an EC of $7.0 \mathrm{dS} \cdot \mathrm{m}^{-1}$ to an $\mathrm{EC}$ of $11.0 \mathrm{dS} \cdot \mathrm{m}^{-1}$ (Fig. 7D). A decrease in the root-to-shoot ratio of I. rubra at an EC of 3.0 and 7.0 $\mathrm{dS} \cdot \mathrm{m}^{-1}$ is likely related to the species' slow and compact plant growth habit, and a relatively high $\mathrm{Cl}^{-}$accumulation in shoot tissue, which 


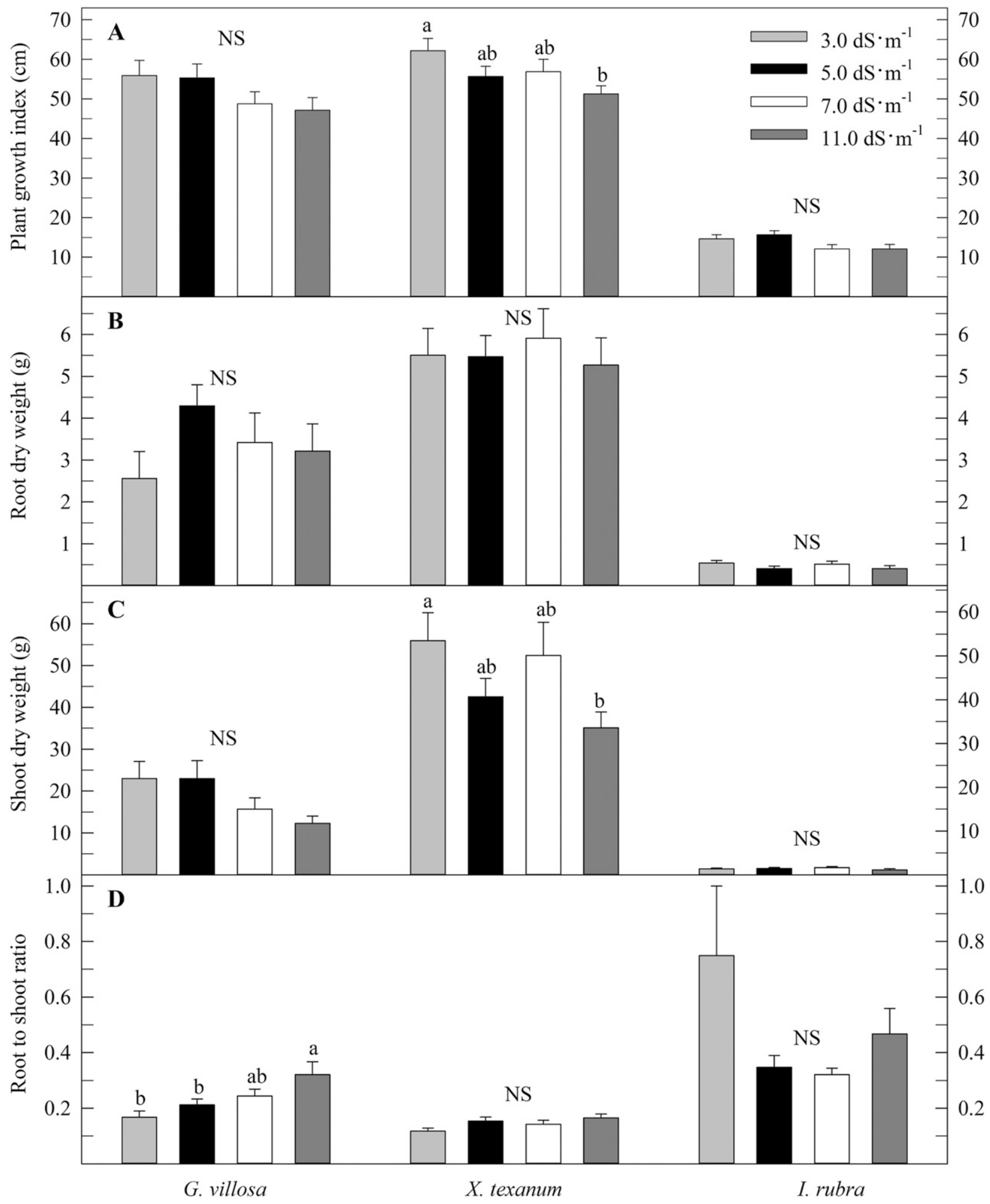

Fig. 7. Effect of electrical conductivity of hydroponic solution on (A) plant growth index, (B) root dry weight, (C) shoot dry weight, and (D) root-to-shoot ratio of Gaura villosa, Xanthisma texanum, and Ipomopsis rubra. Treatment means within each species with the same letters are not different at $P \leq 0.05$. Vertical bars represent SE. NS, nonsignificant across salinity treatments $(P \leq 0.05)$. Means separation conducted by Student-Newman-Keuls multiple comparison $(P \leq$ $0.05)$.

likely increased dry shoot weight. An increase in the root-to-shoot ratio of I. rubra at the highest salinity treatment could be the cause of a significant reduction in plant shoot growth (Fig. 7C), and an increase in lower leaf necrosis compared with the $7.0-\mathrm{dS} \cdot \mathrm{m}^{-1}$ treatment (Fig. 5, Table 3). For example, Cabrera and
Perdomo (2003) found dry weight yields (flower and shoots) of Rosa $\times$ hybrida ('Bridal Pink' rose) increased as the leaf tissue $\mathrm{Cl}^{-}$ concentration increased up to $0.40 \%$, but declined at greater $\mathrm{Cl}^{-}$concentrations.

Ion concentrations. $\mathrm{Na}^{+}, \mathrm{Ca}^{2+}$, and $\mathrm{Cl}^{-}$ concentrations in shoot and root tissues of
G. villosa, X. texanum, and I. rubra were affected differently by increased salinity levels in nutrient solutions, and varied between tissue types (Figs. 8-10). Ion uptake and tissue accumulation depend on plant species or genotype, overall soil or irrigation water salinity level, duration of saline water 


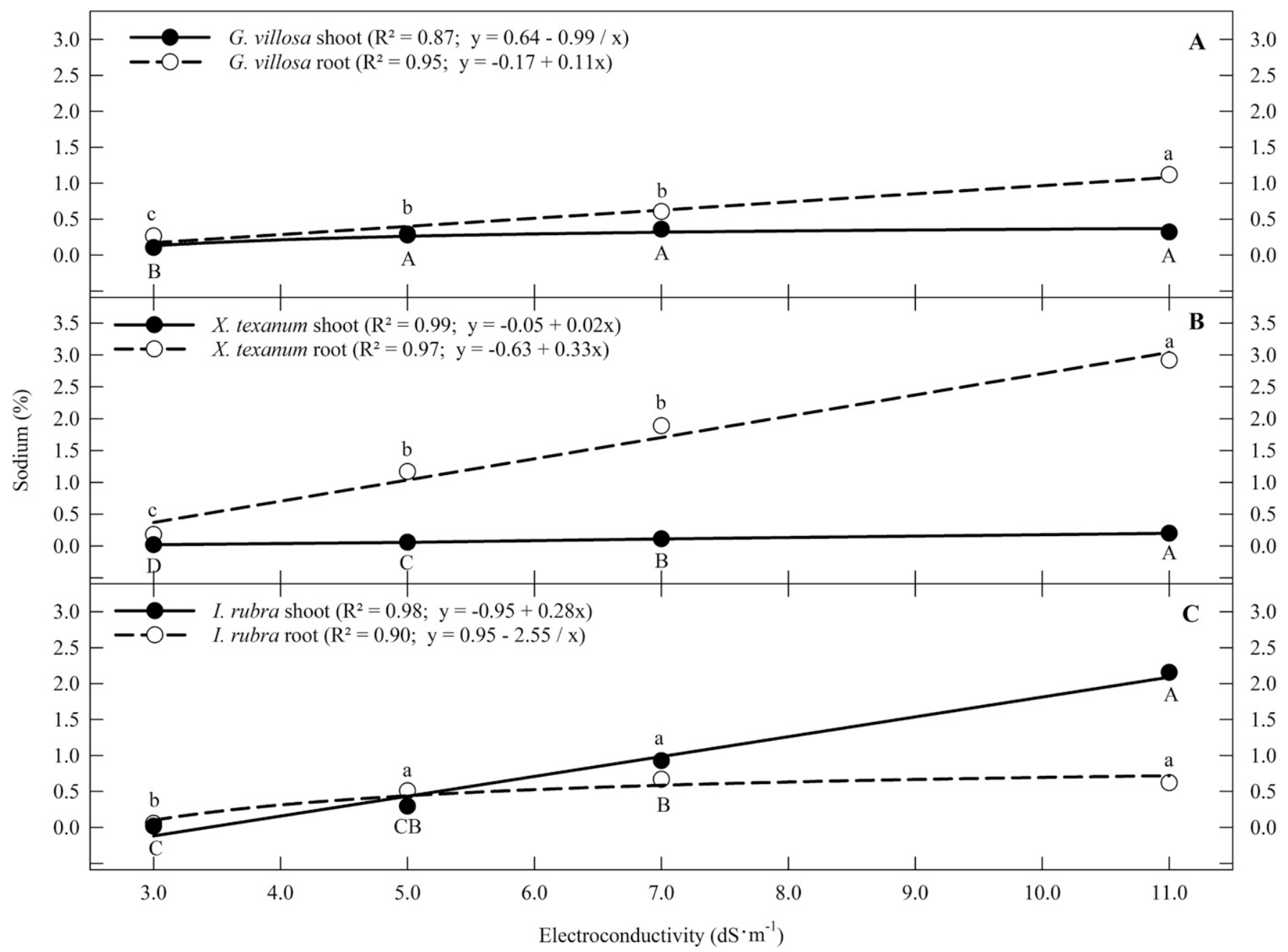

Fig. 8. Regression analysis for sodium ion content as a percentage of dry weight of shoot (solid line) and root (dashed line) tissues of (A) Gaura villosa, (B) Xanthisma texanum, and (C) Ipomopsis rubra treated with control [reverse-osmosis water and nutrient solution, with an electrical conductivity (EC) of $3.0 \mathrm{dS} \cdot \mathrm{m}^{-1}$ ] and three levels of saline solution with an EC of $5.0,7.0$, and $11.0 \mathrm{dS} \cdot \mathrm{m}^{-1}$. Uppercase letters correspond to treatment means over two experiments (2017 and 2019) for shoots (dark symbols), whereas lowercase letters correspond to treatment means for roots (open symbols). Treatment means with the same letter within the same plant tissue are not different at $P \leq 0.05$. Means separation conducted by Student-Newman-Keuls multiple comparison $(P \leq 0.05)$.

irrigation, and the specific ion composition of the soil solution (Grattan and Grieve, 1999; Niu and Cabrera, 2010).

G. villosa and $X$. texanum plants tended to accumulate more $\mathrm{Na}^{+}$in root tissue compared with shoot tissue (Fig. 8A and B), whereas $I$. rubra accumulated more $\mathrm{Na}^{+}$in shoots when compared with roots (Fig. 8C). Root $\mathrm{Na}^{+}$of $G$. villosa and $X$. texanum increased gradually as the salinity of the hydroponic solution increased, and the $\mathrm{Na}^{+}$percentage ranged from $0.27 \%$ to $1.12 \%$, and $0.18 \%$ to $2.92 \%$ of root dry weight, respectively (Fig. 8A and B). On the other hand, root $\mathrm{Na}^{+}$concentrations of I. rubra were different only between the control and the remaining salinity treatments (Fig. 8C). Shoot $\mathrm{Na}^{+}$concentrations of $X$. texanum and I. rubra were affected positively by salinity concentrations, and ranged from $0.02 \%$ to $0.20 \%$, and $0.02 \%$ to $2.15 \%$ of shoot dry weight, respectively (Fig. 8B and C). An increase in shoot $\mathrm{Na}^{+}$content of landscape plants in response to increased salinity levels has been reported in a number of studies. For example, excessive shoot $\mathrm{Na}^{+}$ accumulation in I. rubra plants at the highest salinity level could contribute to older leaf necrosis (Munns and Tester, 2008), greater plant mortality rate (Niu and Rodriguez, 2006b), and the low plant visual rating (Hooks and Niu, 2019). For G. villosa plants, differences in shoot $\mathrm{Na}^{+}$concentrations were observed between the control and the remaining salinity treatments (Fig. 8A). A small increase in shoot $\mathrm{Na}^{+}$compared with $\operatorname{root} \mathrm{Na}^{+}$ concentrations of $X$. texanum plants, and similar shoot $\mathrm{Na}^{+}$accumulations in $G$. villosa plants at an EC of 5.0, 7.0, and $11.0 \mathrm{dS} \cdot \mathrm{m}^{-1}$ indicate an ability of $X$. texanum and $G$. villosa plants to restrict $\mathrm{Na}^{+}$transport to shoots. Niu and Rodriguez (2006b) found greater $\mathrm{Na}^{+}$accumulations in root tissue compared with shoot tissue of Delosperma cooperi (ice plant), which they concluded to be a relatively high-salinity-tolerant plant. Hooks and Niu (2019) also found $\mathrm{Na}^{+}$exclusion from the shoot tissue of Sedum telephium 'Autumn Joy' (autumn joy stonecrop) in response to elevated salinity levels. In addition, Liu et al. (2020) and Niu and Cabrera (2010) indicate salt-tolerant plant species tend to accumulate lesser amounts of salt in their shoot tissue when compared with plant species that are less salt tolerant.

Root $\mathrm{Ca}^{2+}$ concentrations of $G$. villosa and $X$. texanum plants increased significantly with $\mathrm{NaCl}$ and $\mathrm{CaCl}_{2}$ application rates, and ranged from 3.31 to $5.47 \%$, and 3.21 to $4.33 \%$ of root dry weight, respectively (Fig. 9A and B). However, root $\mathrm{Ca}^{2+}$ concentration of I. rubra was unaffected by hydroponic solution salinity (Fig. 9C). Shoot $\mathrm{Ca}^{2+}$ concentration in $G$. villosa plants was greatest at an EC of $5.0 \mathrm{dS} \cdot \mathrm{m}^{-1}$, and no differences were found in shoot $\mathrm{Ca}^{2+}$ concentrations among the control and the remaining salinity treatments (Fig. 9A). Hooks and Niu (2019) noted a gradual decline in shoot $\mathrm{Ca}^{2+}$ content was observed in Sedum telephium 'Autumn Joy' (autumn joy stonecrop) as media salinity increased to $10.0 \mathrm{dS} \cdot \mathrm{m}^{-1}$. A decrease in shoot $\mathrm{Ca}^{2+}$ concentration, even though $\mathrm{NaCl}$ and 


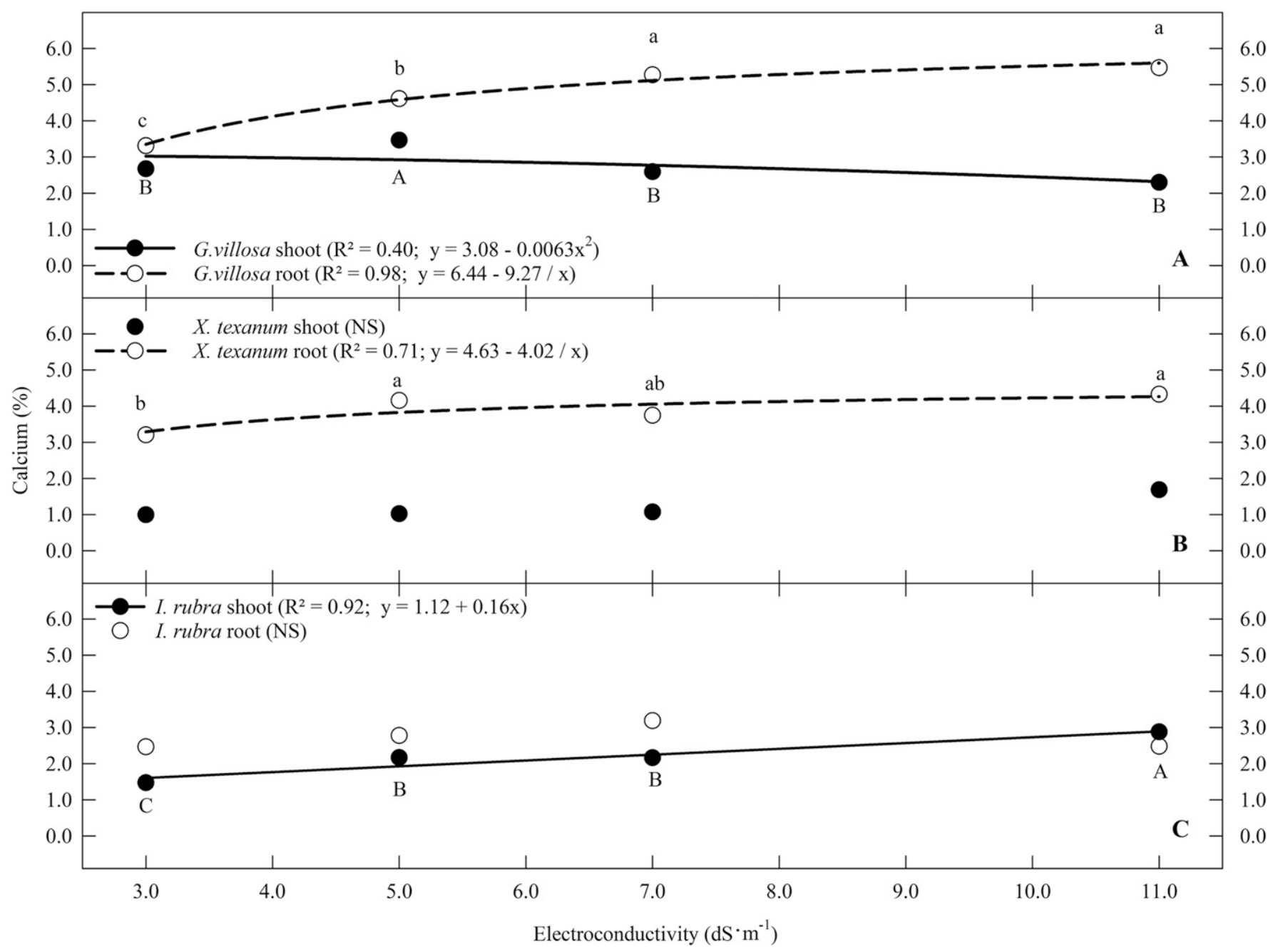

Fig. 9. Regression analysis for calcium ion content as a percentage of dry weight of shoot (solid line) and root (dashed line) tissues of (A) Gaura villosa, (B) Xanthisma texanum, and (C) Ipomopsis rubra treated with control [reverse-osmosis water and nutrient solution, with an electrical conductivity (EC) of 3.0 $\mathrm{dS} \cdot \mathrm{m}^{-1}$ ] and three levels of saline solution with an EC of 5.0, 7.0, and $11.0 \mathrm{dS} \cdot \mathrm{m}^{-1}$. Uppercase letters correspond to treatment means over two experiments (2017 and 2019) for shoots (dark symbols), whereas lowercase letters correspond to treatment means for roots (open symbols). Treatment means with the same letter within the same plant tissue are not different at $P \leq 0.05$. Means separation conducted by Student-Newman-Keuls multiple comparison $(P \leq 0.05)$.

$\mathrm{CaCl}_{2}$ application rates were increased, indicates a $\mathrm{Na}^{+}$antagonistic effect on $\mathrm{Ca}^{2+}$ absorption (Hooks and Niu, 2019; Paudel et al., 2019; Wang et al., 2019). Shoot $\mathrm{Ca}^{2+}$ concentrations of I. rubra increased linearly with increasing salinity levels (Fig. 9C). Wu et al. (2016) found similar increases in shoot $\mathrm{Ca}^{2+}$ concentrations in several species from the Lamiaceae family. Shoot $\mathrm{Ca}^{2+}$ concentrations of $X$. texanum plants did not differ among salinity treatments, although a gradual increase in shoot $\mathrm{Ca}^{2+}$ content was demonstrated with increasing salinity levels (Fig. 9B). Niu and Rodriguez (2006b) also found no differences in $\mathrm{Ca}^{2+}$ content among salinity treatments both in shoot and root tissues for Ceratostigma plumbaginoides (blue leadwood) and Delosperma cooperi (ice plant).

Root $\mathrm{Cl}^{-}$concentrations of $G$. villosa and $X$. texanum increased linearly with an increase in salinity concentration of irrigation solutions, and ranged from 0.75 to $3.55 \%$, and from 0.48 to $4.47 \%$ of root dry weight, respectively (Fig. 10A and B). For I. rubra, an increase in root $\mathrm{Cl}^{-}$content as salinity levels increased was a curvilinear response, with differences found between the control and the remaining salinity treatments (Fig. 10C). Similar to $\operatorname{root} \mathrm{Cl}^{-}$concentrations, accumulation of $\mathrm{Cl}^{-}$in shoots of $G$. villosa and $X$. texanum plants increased linearly with increasing salinity levels, and were $0.42 \%$ to $3.30 \%$, and $0.58 \%$ to $2.38 \%$ of shoot dry weight, respectively (Fig. 10A and B). In similar studies, Wu et al. (2016) and Hooks and Niu (2019) also found an increase in shoot $\mathrm{Cl}^{-}$content as irrigation salinity levels increased for six woody landscape plant species, and four herbaceous perennial ornamental plant species. Shoot $\mathrm{Cl}^{-}$content of I. rubra increased gradually from control to the 7.0$\mathrm{dS} \cdot \mathrm{m}^{-1}$ treatment, and then plateaued at an EC of $11.0 \mathrm{dS} \cdot \mathrm{m}^{-1}$ (Fig. 10C). A similar $\mathrm{Cl}^{-}$ accumulation in root and shoot tissues of $G$. villosa indicates the plant's ability to tolerate high internal $\mathrm{Cl}^{-}$concentrations, and the lack of $\mathrm{Cl}^{-}$exclusion mechanisms from shoots. Shoot tissue $\mathrm{Cl}^{-}$tolerance along with a $\mathrm{Na}^{+}$ exclusion mechanism is consistent with re- sults from a number of salinity studies (Cabrera and Perdomo, 2003; Niu and Rodriguez, 2006b). Nearly twice as much $\mathrm{Cl}^{-}$ accumulation at the highest salinity levels in root tissue, compared with shoot tissue of $X$. texanum plants, indicates the ability of $X$. texanum to restrict $\mathrm{Cl}^{-}$movement in shoots (Fig. 10B). Ion exclusion from shoot tissue is considered to be an important mechanism of salt tolerance (Munns and Tester, 2008; Niu and Cabrera, 2010). Older leaf necrosis and premature leaf drop of G. villosa and I. rubra plants were observed for all salinity treatments, with a more evident effect at the greatest $\mathrm{NaCl}$ and $\mathrm{CaCl}_{2}$ application levels (Fig. 6). Partitioning of $\mathrm{Cl}^{-}$in older leaves with further leaf abscission indicates another mechanism of salt tolerance, by which saltadapted plants remove $\mathrm{Cl}^{-}$ions from their shoots (Cheeseman, 1988; Deeter, 2002). However, for salt-sensitive plant species such as Poliomintha longiflora (Mexican oregano), Ajuga reptans 'Burgundy Glow' (bugleweed), and Scutellaria suffrutescens 'Pink Skullcap' (cherry skullcap), excessive $\mathrm{Cl}^{-}$ 


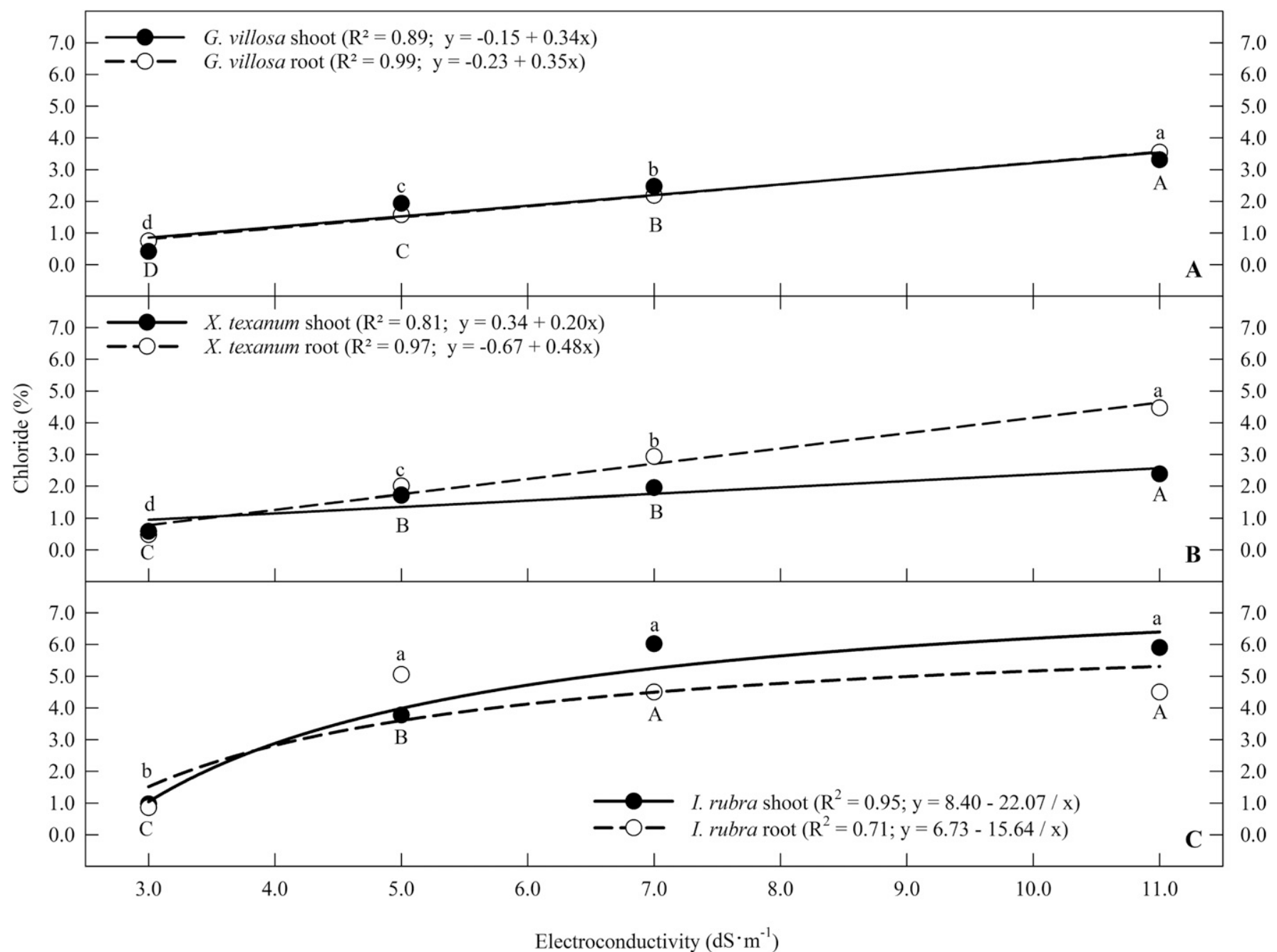

Fig. 10. Regression analysis for chloride ion content as a percentage of dry weight shoot (solid line) and root (dashed line) tissues of (A) Gaura villosa, (B) Xanthisma texanum, and (C) Ipomopsis rubra treated with control [reverse-osmosis water and nutrient solution, with an electrical conductivity (EC) of 3.0 $\mathrm{dS} \cdot \mathrm{m}^{-1}$ ] and three levels of saline solution with an EC of 5.0, 7.0, and $11.0 \mathrm{dS} \cdot \mathrm{m}^{-1}$. Uppercase letters correspond to treatment means over two experiments (2017 and 2019) for shoots (dark symbols), whereas lowercase letters correspond to treatment means for roots (open symbols). Treatment means with the same letter within the same plant tissue are not different at $P \leq 0.05$. Means separation conducted by Student-Newman-Keuls multiple comparison $(P \leq 0.05)$.

accumulations at an EC of $10.0 \mathrm{dS} \cdot \mathrm{m}^{-1}$ can result in severe leaf injury, and eventual plant death (Wu et al., 2016). In addition, Hooks and Niu (2019) suggested moderate foliar damage in Sedum rupestre 'Angelina' (Angelina stonecrop) and Evolvulus glomeratus 'Blue Daze' (blue daze) to be associated with high shoot $\mathrm{Na}^{+}$and $\mathrm{Cl}^{-}$accumulation, which could cause cytosolic plant damage. Paudel et al. (2019) concluded Aquilegia barnebyi (oil shale columbine) was the least salt-tolerant perennial among tested species with the most reduced visual quality and growth while accumulating high amount of $\mathrm{Na}^{+}$and $\mathrm{Cl}^{-}$in shoot tissue. Therefore, poor performance of I. rubra plants with increased salinity levels could be attributed to shoot $\mathrm{Na}^{+}$and $\mathrm{Cl}^{-}$accumulations to toxic levels, which promote salt damage symptoms.

Excreted salt was found on older leaves and on the lower portion of stems on numerous G. villosa plants at EC levels of 7.0 and $11.0 \mathrm{dS} \cdot \mathrm{m}^{-1}$ (Fig. 11A and B). Salt excretion is one of the most efficient mechanisms of salinity tolerance, and it prevents accumula- tion of excessive salt within plant tissues (Deeter, 2002; Hasanuzzaman et al., 2014). Plants that excrete salt via salt glands absorb saline water from the soil and move saline water through plant tissues until the saline water evaporates into the air (Yensen and Biel, 2006). Although additional research is required, salt-conducting plants have a great potential to be used in remediation of saltaffected soils (Jesus et al., 2015; Yensen and Biel, 2006). Various salt ions can be secreted onto leaf surfaces. However, excretion of $\mathrm{Na}^{+}$ and $\mathrm{Cl}^{-}$ions was noted to be predominant over other ions (Ding et al., 2010). Therefore, salt excretion by $G$. villosa plants could contribute to low $\mathrm{Na}^{+}$shoot concentrations, and similar shoot and $\operatorname{root} \mathrm{Cl}^{-}$accumulations.

This research indicates $X$. texanum and $G$. villosa plants were tolerant to hydroponic solution salinity up to $11.0 \mathrm{dS} \cdot \mathrm{m}^{-1}$. In addition, I. rubra plants were identified as moderately salt tolerant, and may display acceptable appearance and growth if irrigated with reclaimed water with an EC less than 7.0 $\mathrm{dS} \cdot \mathrm{m}^{-1}$ (Miyamoto et al., 2004). Several mechanisms of salt tolerance were observed among tested wildflower species. It appears $X$. texanum has a high ability to exclude $\mathrm{Na}^{+}$, $\mathrm{Ca}^{2+}$, and $\mathrm{Cl}^{-}$from shoot tissue, and accumulate these ions within the root tissue. On the other hand, I. rubra tended to accumulate $\mathrm{Na}^{+}$, $\mathrm{Ca}^{2+}$, and $\mathrm{Cl}^{-}$mainly in shoot tissue, which likely instigated ion toxicity and led to a high mortality rate at the greatest salinity level. $G$. villosa plants had a more complex response to increased hydroponic salinity levels, which included a combination of traits associated with salinity tolerance. Also, G. villosa plants were able to accumulate progressively similar $\mathrm{Cl}^{-}$concentrations in shoot and root tissue, while selectively excluding $\mathrm{Na}^{+}$and $\mathrm{Ca}^{2+}$ from shoot tissue. In addition, salt excretion from glandular hairs, and older leaf abscission were observed in numerous $G$. villosa plants as the EC of hydroponic solutions increased. Although continued research is essential, results suggest great potential for these native Texas wildflower species in landscapes using reclaimed irrigation water and in landscapes with soil salinity concerns. 


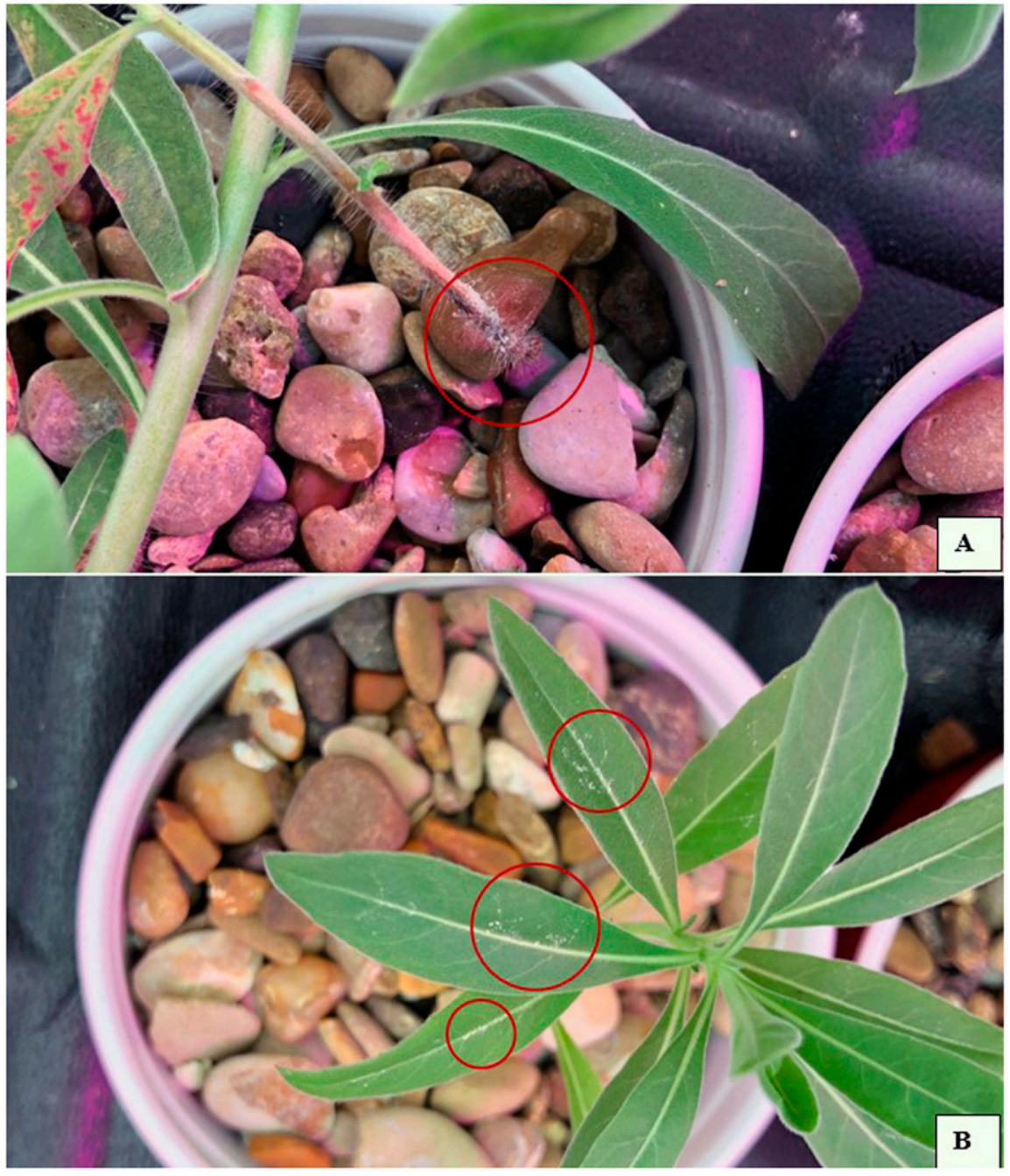

Fig. 11. Salt excretion by Gaura villosa via glandular hairs on (A) lower portion of stem and (B) leaves at an electrical conductivity of 7.0 - and $11.0-\mathrm{dS} \cdot \mathrm{m}^{-1}$ salinity treatments. Photos taken during the second experiment (2019).

\section{Literature Cited}

Acosta-Motos, J.R., P. Diaz-Vivancos, S. Álvarez, N. Fernández-García, M. Sanchez-Blanco, and J.A. Hernández. 2015. Physiological and biochemical mechanisms of the ornamental Eugenia myrtifolia $\mathrm{L}$. plants for coping with $\mathrm{NaCl}$ stress and recovery. Planta 242:829-846.

Cabrera, R.I. and P. Perdomo. 2003. Reassessing the salinity tolerance of greenhouse roses under soilless production conditions. HortScience 38:533-536.

Cassaniti, C., D. Romano, and T.J. Flowers. 2012. The response of ornamental plants to saline irrigation water, p. 131-158. In: I. Garcia-Garizabal (ed.) Irrigation: Water management, pollution and alternative strategies. In Tech, Rijeka, Croatia.

Cheeseman, J.M. 1988. Mechanisms of salinity tolerance in plants. Plant Physiol. 87:547-550.

Deeter, L.M. 2002. Sodium chloride tolerance of selected herbaceous perennials and the effects of sodium chloride on osmotic adjustment and ionic uptake in three species of herbaceous perennials. Ohio State Univ., Ann Arbor, PhD Diss. UMI no. 3039464.

Diggs, G.M., B.L. Lipscomb, and R.J. O'Kennon. 1999. Shinners \& Mahler's illustrated flora of north central Texas. Botanical Research Institute of Texas, Fort Worth, TX.
Ding, F., J.C. Yang, F. Yuan, and B.S. Wang. 2010. Progress in mechanism of salt excretion in recretohalopytes. Front. Biol. 5:164-170.

Ferrarezi, R.S. and D.S. Bailey. 2019. Basil performance evaluation in aquaponics. HortTechnology 29:85-93.

Ganjegunte, G., A. Ulery, G. Niu, and Y. Wu. 2017. Effects of treated municipal wastewater irrigation on soil properties, switchgrass biomass production and quality under arid climate. Ind. Crops Prod. 99:60-69.

Gaylord, B. and T.P. Egan. 2006. How salts of sodium, potassium, and sulfate affect the germination and early growth of Atriplex acanthocarpa (Chenopodiaceae), p. 1-9. In: M.A. Khan and D.J. Weber (eds.). Ecophysiology of high salinity tolerant plants. Tasks for vegetation science, vol. 40. Springer, Dordrecht.

Gioannini, R., M. Al-Ajlouni, R. Kile, D. VanLeeuwen, and R.S. Hilaire. 2018. Plant communities suitable for green roofs in arid regions. Sustainability 10:1755-1775.

Grattan, S.R. and C.M. Grieve. 1999. Salinitymineral nutrient relations in horticultural crops. Scientia Hort. 78:127-157.

Grieve, C., L. Wu, L. Rollins, and A. Harivandi. 2008. Tolerance by landscape plants of salinity and of specific ions, p. 103-161. In: K. Tanji, S. Grattan, C. Grieve, A. Harivandi, L. Rollins, D.
Shaw, B. Sheikh, and L. Wu (eds.). A comprehensive literature review on salt management guide for landscape irrigation with recycled water in coastal southern California. University of California-Davis, Davis, CA. 28 Mar. 2018. $<\mathrm{http}: / /$ www.salinitymanagement.org/>.

Hamilton, A.J., F. Stagnitti, X. Xiong, S.L. Kreidl, K.K Benke, and P. Maher. 2007. Wastewater irrigation: The state of play. Vadose Zone J. 6:823-840.

Hasanuzzaman, M., N. Kamrun, M.M. Alam, P.C. Bhowmik, A. Hossain, M.M. Rahman, P. Majeti, M. Ozturk, and M. Fujita. 2014. Potential use of halophytes to remediate saline soils. BioMed Res. Intl. 2014:1-12.

Hooks, T. and G. Niu. 2019. Relative salt tolerance of four herbaceous perennial ornamentals. Horticulturae 5:1-10.

Hopwood, J. 2013. Roadsides as habitat for pollinators: Management to support bees and butterflies. Presented at the Xerces Society for Invertebrate Conservation, ICOET 2013, Scottsdale, Arizona, 23-27 June 2013.

Jesus, J.M., A.S. Danko, A. Fiúza, and M. Borges. 2015. Phytoremediation of salt-affected soils: A review of processes, applicability, and the impact of climate change. Environ. Sci. Pollut. Res. Intl. 22:6511-6525.

Kalantari, E., A. Hassanli, G.A. Ghanbarian, A.A. Ghaemi, and S.R. Mousari. 2018. Local desalination treatment plant wastewater reuse and evaluation potential absorption of salts by the halophyte plants. Eurasian J. Soil Sci. 7:43-50.

Kjelgren, R., L. Rupp, and D. Kilgren. 2000. Water conservation in urban landscapes. HortScience 35:1037-1040.

Kjelgren, R., L. Wang, and D. Joyce. 2009. Water deficit stress responses of three native Australian ornamental herbaceous wildflower species for water-wise landscapes. HortScience 44:1358-1365.

Kotzen, B. 2004. Plant use in desert climates: Looking forward to sustainable planting in the Negev and other world deserts. Acta Hort. 643:39-49.

Kreeb, K. 1974. Plants in saline habitats. Naturwissenschaften 61:337-343.

Lee-Mäder, E., B. Borders, and A. Minnerath. 2013. Establishing pollinator meadows from seed. The Xerces Society for Invertebrate Conversation, Portland, OR.

Liu, Q., Y. Sun, J. Altland, and G. Niu. 2020. Morphological and physiological responses of Cornus alba to salt and drought stresses under greenhouse conditions. HortScience 55:224-230.

McKenney, C.B., T.R. Mahato, and U.K. Schuch. 2016. Salinity tolerance of ornamental grasses adapted to semi-arid environments. Acta Hort. 1112:95-100

Miyamoto, S., I. Martinez, M. Padilla, A. Portillo, and D. Ornelas. 2004. Landscape plant lists for salt tolerance assessment. Texas A\&M Agr. Research Center at El Paso and El Paso Water Utilities. April 2004.

Montesano, F. and M.W. Van Iersel. 2007. Calcium can prevent toxic effects of $\mathrm{Na}^{+}$on tomato leaf photosynthesis but does not restore growth. J. Amer. Soc. Hort. Sci. 132:310-318.

Morris, K.N. and R.C. Shearman. 2000. NTEP turfgrass evaluation guidelines. National Turfgrass Evaluation Program, Beltsville, MD. 12 Mar. 2017. <http://www.ntep.org/pdf/ratings. pdf $>$.

Munns, R. 2005. Genes and salt tolerance: Bringing them together. Plant Physiol. 167:645-663.

Munns, R. and M. Tester. 2008. Mechanisms of salinity tolerance. Annu. Rev. Plant Biol. 59:651-681.

Niu, G. and R.I. Cabrera. 2010. Growth and physiological responses of landscape plants 
to saline water irrigation: A review. HortScience 45:1605-1609.

Niu, G. and D.S. Rodriguez. 2006a. Relative salt tolerance of five herbaceous perennials. HortScience 41:1493-1497.

Niu, G. and D.S. Rodriguez. 2006b. Relative salt tolerance of selected herbaceous perennials and groundcovers. Scientia Hort. 110:352-358.

Niu, G., D.S. Rodriguez, and L. Aguiniga. 2007. Growth and landscape performance of ten herbaceous species in response to saline water irrigation. J. Environ. Hort. 25:204-210.

Niu, G., D.S. Rodriguez, and C. McKenney. 2012a. Response of selected wildflower species to saline water irrigation. HortScience 47:13511355.

Niu, G., D.S. Rodriguez, and T. Starman. 2010. Response of bedding plants to saline water irrigation. HortScience 45:628-636.

Niu, G., Y. Sun, and J.G. Masabni. 2018. Impact of low and moderate salinity water on plant performance of leafy vegetables in a recirculating NFT system. Horticulturae 4:1-13.

Niu, G., M. Wang, D.S. Rodriguez, and D. Zhang. 2012b. Response of zinnia plants to saline water irrigation. HortScience 47:793-797.
Paudel, A., J.J. Chen, Y. Sun, Y. Wang, and R. Anderson. 2019. Salt tolerance of Sego Supreme ${ }^{\mathrm{TM}}$ plants. HortScience 54:2056-2062.

Pessarakli, M. and D.M. Kopec. 2009. Screening various ryegrass cultivars for salt stress tolerance. J. Food Agr. Environ. 7:739-743.

Qian, Y.L., J.M. Fu, J. Klett, and S.E. Newman. 2005. Effects of long-term recycled wastewater irrigation on visual quality and ion concentrations of ponderosa pine. J. Environ. Hort. 23:185-189.

Trajkova, F., N. Papadantonakis, and D. Savvas. 2006. Comparative effects of $\mathrm{NaCl}$ and $\mathrm{CaCl}_{2}$ salinity on cucumber grown in a closed hydroponic system. HortScience 41:437-441.

U.S. Department of Agriculture. 2018. Natural Resources Conservation Service, The Plants Database. National Plant Data Team, Greensboro, NC. 25 Feb. 2018. <https://plants.usda. gov/core/profile? >.

Veatch-Blohm, M.E., D. Sawch, N. Elia, and D. Pinciotti. 2014. Salinity tolerance of three commonly planted Narcissus cultivars. HortScience 49:1158-1164.

Wang, Y., Y. Sun, G. Niu, C. Deng, Y. Wang, and J. Gardea-Torresdey. 2019. Growth, gas exchange, and mineral nutrients of ornamental grasses irrigated with saline water. HortScience 54:1840-1846.

Wasowski, S. and A. Wasowski. 2000. Native Texas plants: Landscaping region by region. 2nd ed. Lone Star Books, Houston, TX.

Wu, S., Y. Sun, G. Niu, G.L.G. Pantoja, and A.C. Rocha. 2016. Responses of six Lamiaceae landscape species to saline water irrigation. J. Environ. Hort. 34:30-35.

Yadav, S., M. Irfan, A. Ahmad, and S. Hayat. 2011. Causes of salinity and plant manifestations to salt stress: A review. J. Environ. Biol. 32:667685.

Yensen, N.P. and K.Y. Biel. 2006. Soil remediation via salt-conduction and the hypotheses of halosynthesis and photoprotection, p. 313314. In: M.A. Khan and D.J. Weber (eds.). Ecophysiology of high salinity tolerant plants. Springer, Netherlands.

Zollinger, N., R. Koenig, T. Cerny-Koenig, and R. Kjelgren. 2007. Relative salinity tolerance of intermountain western United States native herbaceous perennials. HortScience 42:529534. 